Primljen / Received: 15.10.2015.

Ispravljen / Corrected: 17.4.2017.

Prihvaćen / Accepted: 5.7.2017.

Dostupno online / Available online: 10.3.2018.

\section{Development of a roughness estimation model for low volume roads}

Authors:

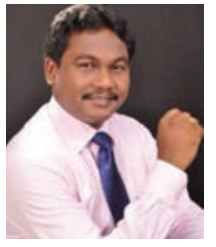

Makendran Chandrakasu, MCE

Anna University, India

Faculty of Civil Engineering

makendran2006@gmail.com

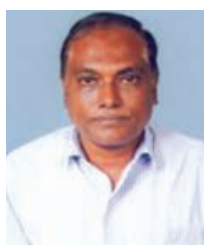

Assoc.Prof. Murugasan Rajiah, PhD. CE Anna University, India

Faculty of Civil Engineering

murugasanr@rediffmail.com

\section{Makendran Chandrakasu, Murugasan Rajiah}

\section{Development of a roughness estimation model for low volume roads}

Pavement roughness is one of essential performance indicators that are used in road maintenance. A model was developed in this study to obtain roughness value from easily measurable distress values, namely cracking and potholes, for low-volume roads in India. The data collected at 173 in-service flexible pavements were utilised for model development. Using the model developed in this study, a satisfactory roughness value can indirectly be obtained from the cracking and potholing data, even without the use of a roughness measuring device.

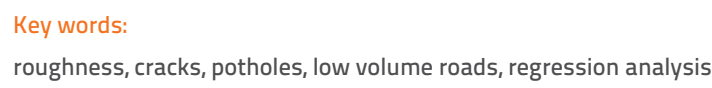

Stručni rad

Makendran Chandrakasu, Murugasan Rajiah

Izrada modela za ocjenu ravnosti na cestama s malim volumenom prometa

Ravnost vozne površine kolnika jedan je od osnovnih pokazatelja stanja kolnika koji se koriste u održavanju cesta. U okviru ovog istraživanja izrađen je model za određivanje ravnosti na temelju lako mjerljivih pokazatelja oštećenosti, a to su pukotina i udarnih rupa, na cestama s malim volumenom prometa u Indiji. Za izradu modela korišteni su podaci prikupljeni na 173 ceste s asfaltnim zastorom. Primjenom modela izrađenog u ovom radu može se posrednim putem, čak i bez primjene uređaja za mjerenje ravnosti, dobiti zadovoljavajuća vrijednost ravnosti na temelju podataka o pukotinama i udarnim rupama.

Ključne riječi:

ravnost, pukotine, udarne rupe, ceste s malim volumenom prometa, regresijska analiza

Fachbericht

Makendran Chandrakasu, Murugasan Rajiah

Erstellung eines Modells für die Beurteilung der Ebenmäßigkeit von Straßen mit geringem Verkehrsaufkommen

Die Ebenmäßigkeit der befahrbaren Fläche der Fahrbahn ist eine der grundlegenden Indikatoren für den Zustand der Fahrbahn, der bei der Instandhaltung der Straßen herangezogen wird. Im Rahmen dieser Untersuchung wurde ein Modell für die Bestimmung der Ebenmäßigkeit aufgrund leicht messbarer Beschädigungsindikatoren erstellt, und dies sind Risse und Schlaglöcher auf Landstraßen mit geringem Verkehrsaufkommen in Indien. Für die Erstellung des Durch Anwendung des in dieser Abhandlung erstellten Modells ist es möglich auf indirektem Wege, sogar ohne Anwendung des Gerätes zur Messung der Ebenmäßigkeit, einen zufriedenstellenden Wert der Ebenmäßigkeit aufgrund der Daten über Risse und Schlaglöcher zu erhalten.

Schlüsselwörter:

Ebenmäßigkeit, Risse, Schlaglöscher, Straßen mit geringem Verkehrsaufkommen, Regressionsanalyse 


\section{Introduction}

The transport infrastructure system plays a very important role in the development of economical, social, cultural and employment opportunities in all countries. The development of a country is based on the growth of its road network. The road network usually has an asset value that represents a significant proportion of national wealth. In India, road network consists of nearly 4.4 million km of roads [1]. Thus, India has the second largest road network in the world. In India, roads are classified into five categories, namely expressways, national highways, state highways, other district roads, and village roads. Compared to other road categories, traffic volume on most village roads is very low (with less than 150 commercial vehicles per day). Presently, the total length of low volume village roads in India amounts to approximately $2,750,000 \mathrm{~km}$ [1]. Village roads connect small villages with one another, while also ensuring connection with other road categories. These roads are directly linked to the agricultural and production sectors. Poverty is one of incurable diseases of rural areas in India, and these village roads have a vital role in curbing the poverty rate.

The Government of India is investing significant funds in the construction of low volume village roads. But the problem of maintaining these roads has proven to be a very difficult task for the country. Several pavement performance models have been developed in many countries by various agencies and researchers for the planning, design, construction, and maintenance of pavements. But these models are location specific and have their own limitations.

The AASHO Road Test was carried out in 1962 by the Highway Research Board at Ottawa, USA. The AASHO model measures the present serviceability index based on the age and traffic load of flexible and rigid pavements [2].

Querioz and Hudson [3] developed paved road deterioration models from the year 1975 to 1981 under the BrazilUnited Nations Development Project. In this study, models were developed for the roughness progression, cracking initiation, and cracking progression. The cracking initiation model predicts the number equivalent to 80 -kilonewton single axles to initiate $1 \mathrm{~mm}$ wide cracks, and the modified structural number is employed as an explanatory variable. For the progression of cracking and roughness, the explanatory variables used are the modified structural number, age, traffic loading, and surface deflection.

In 1994, the Central Road Research Institute, India, developed four performance prediction models for Indian roads, using the following distresses: roughness, cracking, ravelling, and potholes. The models were based on the data collected from National Highways (NH) and State Highways (SH) in Indian states of Rajasthan, Gujarat, Uttar Pradesh and Haryana [4]. The roughness model has important independent variables: age, traffic load, and structural number. The cracking model has important independent variables, namely the structural number and traffic load. The potholes model has important independent variables, i.e. the total pavement layer thickness, structural number, and traffic load. The ravelling model has important variables, i.e. the traffic load and construction quality.

Bennet and William [5], developed highways development and management models for eight distresses, namely the cracking, ravelling, potholing, edge break, rutting, roughness, texture depth, and skid resistance, using the data collected from various countries such as Kenya, Romania, India, Thailand, Pakistan, Bangladesh, Brazil, Kosovo, Nepal, Mexico, Vietnam, Morocco, and Kyrgyz. The prediction models have the following significant independent variables:

- Significant independent variables of the cracking model are: structural number, thickness of surface layers, construction defect indicator, traffic loading, and cracking retardation with time due to maintenance.

- Significant independent variables of the ravelling model are: pavement age, traffic loading, ravelling retarding factors due to maintenance of road, and defects in construction.

- Significant independent variables of the potholes model are: traffic loading, total thickness of bituminous surfacing, precipitation and defects in construction.

- Significant independent variables of the edge break model are: traffic loading, elevation difference from pavement to shoulder and precipitation.

- Significant independent variables of the rutting model are: structural number, traffic loading, total thickness of bituminous surfacing, and construction defect indicator.

- Significant independent variables of the roughness model are: pavement age, structural number, traffic loading, total thickness of surfacing layers, and environmental conditions in terms of temperature and fluctuation in moisture.

- Significant independent variables of the texture depth model are: traffic loading, and initial texture depth.

- Significant independent variables of the skid resistance model are: traffic loading, and annual average texture depth.

These models require several input variables, which are very complex and computation intensive. This HDM-IV model is an economic analysis tool as well as a decision making tool [5].

Ricardo et al. [6] developed a Roughness Index model in which independent variables are the soil subgrade, pavement layers, road traffic, and climatic conditions. The study was carried out on approximately 204 pavement sections in the United States. The results obtained showed that a good correlation of regression analysis can be established with the $\mathrm{R}^{2}$ Value of 0.93 .

Smith and Tighe [7] developed a roughness index model for the asphalt pavement overlay on Canadian roads. The model was developed using the Long Term Pavement Performance 
(LTPP) data from Canada, where a total of 53 test sections were evaluated and the data were collected during the period extending to approximately 13 years. In this model, important variables are the overlay thickness, subgrade, and environmental conditions in terms of climate. Serdal [8] developed the pavement serviceability model for flexible pavements using the ANN technique. This model calculates the serviceability index using important variables, i.e. the longitudinal cracking, rut depth, cracking, slope variance, and patches.

Ankit et al. [9] calculated both structural and functional response of a low-volume road for different types of terrain and climatic conditions. The model considered 13 plain and 5 hilly stretches in different districts of the Uttar Pradesh and Uttarakhand States in India. Significant independent variables of the model are the California Bearing Ratio (CBR), age of road pavement, traffic, and thickness of the pavement. They were related to riding quality in terms of the International Roughness Index.

Amarendra et al. [10] developed a model for estimating International Roughness Index (IRI) of pavements. Five important explanatory variables considered in this study were cracking, potholes, patching, rutting, and ravelling. The data for this study were collected from national highways, state highways and major district roads.

Sugeng [11] developed a traffic simulation model to predict initiation and progression of cracks on flexible pavements. Independent variables used by this model are the current condition, pavement strength, age, environment, and traffic. Rajendra et al. [12], developed a relationship between the roughness and visible surface distresses, namely the cracking, potholes, patching, rutting, ravelling, and edge failure. The data for this study were collected from village roads in the districts of Jhunjhunu and Churu of the State of Rajasthan in India. Vandana et al. [13] attempted to model pavement deterioration of low volume roads using regression analysis. The model considers the Pavement Condition Index (PCI) as dependent variable, as well as the following independent variables: Commercial Vehicles Per Day (CVPD), annual rainfall, and subgrade moisture content.

Satish et al. [14] established a relationship between roughness and pavement distress parameters such as cracking, patchwork, ravelling, potholes, and rutting depth. This study considered 510 road sections on national highways throughout India.

The following observations can be made based on the above literature review:

- Pavement performance models available for low volume village roads are very limited.

- Roughness has been defined in all studies as an important performance indicator.

- International Roughness Index (IRI) has been accepted globally as one of important indicators for rating pavement condition.
- The roughness value is influenced by other distresses such as cracking, potholing, etc.

The pavement performance models available in India are meant for high-volume roads only. Due to unavailability of scientific performance models for low-volume roads, the maintenance of these roads has become a challenging task. In the absence of scientific performance models, the best alternative available to maintenance teams for quantitative estimation of pavement condition is to measure and specify the roughness value in $\mathrm{m} / \mathrm{km}$. The roughness value indicates the cumulative surface unevenness in meters per each kilometre of the road. Hence, it would be extremely helpful to specify the roughness value of pavements so as to make well-founded maintenance strategy decisions. In India, the agencies maintaining low volume village roads lack skilled manpower, and it is very difficult for them to take appropriate precautions when defining roughness value with bump integrator. Moreover, due to insufficient funding, these agencies are not equipped with bump integrators at all.

Since good correlation is reported in the literature between roughness value and other easily measurable distresses, an attempt has been made in this study to establish the relationship between roughness and other two commonly observed distresses on low volume village roads, namely cracking and potholes. Cracking and potholes can be measured with simple measuring tape, without requiring skilled manpower. The roughness value can be obtained indirectly from the values of cracking and potholing, and the use of bump integrator for measuring roughness value can be eliminated if desired.

The Thiruvallur District in the state of Tamil Nadu in India has been chosen as the study area. This district extends over an area of 3,422 square kilometres, and the population density amounts to 1,100 residents per sq.km. There are 820 villages in the district. In consultation with the Rural Road and Panchayat Raj Department Officials, 173 test sections, each $200 \mathrm{~m}$ in lengths, were selected for the study of low volume village roads.

In this study, the work was carried out in five stages. In the first stage, the existing 173 in-service low volume roads with flexible pavements were identified as test sections for the study. In the second stage, important pavement distresses such as cracking, potholes, and roughness, were measured on the identified road stretches. In the third stage, the roughness model was developed as a function of other distresses, namely cracking and potholing, using the Multiple Linear Regression Analysis (MLRA). The model validation and sensitivity analysis were carried out in the fourth stage. The ground truth verification was made in the fifth stage. Finally, in the sixth stage, conclusions were drawn and appropriate recommendations were made. The flow chart showing the methodology is given in Figure 1. 


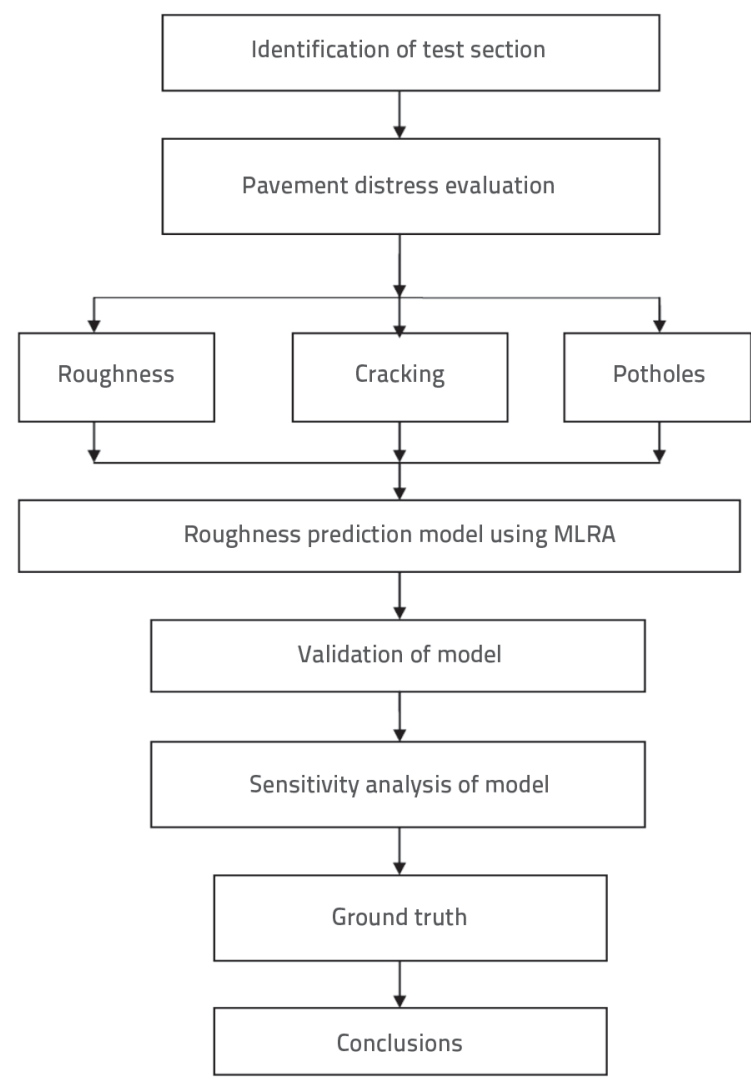

Figure 1. Flow chart showing methodology

\subsection{Traffic conditions and pavement structure specifications}

The maximum and minimum traffic volumes observed on 173 test sections amount to 9 and 2 Commercial Vehicles Per Day (CVPD). The pavement has been designed to carry a single wheel load of $5100 \mathrm{~kg}$ with the total pavement thickness of $295 \mathrm{~mm}$. The pavement composition design procedures suggested by the Indian road congress for rural roads (IRC SP 20: 2002, Manual for rural roads) were followed by rural road authorities.

All test sections were constructed with gravel subbase 125 $\mathrm{mm}$ in thickness, water-bound macadam (WBM) base course $150 \mathrm{~mm}$ in thickness, and premix carpet (PC) bituminous surface course $20 \mathrm{~mm}$ in thickness. The materials quality and construction specifications furnished in IRC SP-20: 2002 were observed during construction of these test sections [15].

\subsection{Selection of study sections}

This criteria were adopted for the selection of study sections:

- Selection of village roads with low traffic volume (less than 150 (VPD).

- Selection of village roads with different age groups.

- Sections on straight reaches and plain terrains.

- Sections without crossroads, cross drainage works, and habitations.
- Sections with uniformity in longitudinal and transverse directions, with regard to crust composition, sub grade, drainage and surface conditions to the extent possible.

\subsection{Data collection}

The distresses such as roughness, cracking and potholes were measured on 173 low-volume village road test sections with flexible pavement. The data were collected on all 173 test sections of different age in February 2014.

\section{Roughness}

The roughness measurements were taken with the towed Fifth Wheel Bump Indicator (MORTH 2004), which is one of the standard devices for measuring roughness in India. The output of this device is measured in $\mathrm{mm} / \mathrm{km}$ or $\mathrm{m} / \mathrm{km}$. The readings were taken on the outer wheel path in both directions, at a distance of $0.6 \mathrm{~m}$ from the edges of the pavement. Three consistent readings were obtained and the average of these three readings were taken as the roughness value. The following precautions were taken during measurements:

- The speed of the vehicle was maintained uniform at approximately $30 \mathrm{~km} / \mathrm{h} \pm 2 \mathrm{~km} / \mathrm{h}$. This speed was attained before reaching the test section, and attempt was made to maintain a constant speed for some distance before reaching the test section.

- Considering the need to maintain consistency during the data collection phase, the same bump integrator unit was used for all the test sections.

- For non-experimental running, the unit was run on towing wheel.

- The towed fifth wheel bump integrator was periodically calibrated before the measurement with a standard bump integrator which was used for calibration purposes only [16].

\section{Cracking}

For measurement purposes, all types of cracks were combined together and the affected area was marked in the form of a square or rectangle. The length and breadth of distressed areas were measured by tape. In case of single longitudinal and transverse cracks, the crack length was measured and the effective width was taken to be $300 \mathrm{~mm}$. In each segment, the total area of cracking was calculated and entered as a percentage of segment area [4].

\section{Potholes}

For measurement purposes, potholes were combined together and the affected area was marked in the form of a square or rectangle. The length and breadth of distressed areas were measured by tape. In each segment, the total area of potholes was calculated and entered as a percentage of segment area [4].

\section{Traffic data collection}

The traffic surveys were conducted for seven consecutive days round the clock, by engaging adequate number of enumerators. 
From the traffic survey data, the number of commercial vehicles per day (CVPD) was counted for each section, and this information was used in model development [17].

\section{Development of roughness model}

The range of distress data collected and used for model development and validation is given in Table 1.

Table 1. Range of distress data used for model development and validation

\begin{tabular}{|c|c|c|c|c|c|}
\hline Distress & Notation & Unit & Minimum & Maximum & Mean \\
\hline Roughness & $\mathrm{ROU}$ & {$[\mathrm{m} / \mathrm{km}]$} & 3 & 9 & 6 \\
\hline Cracking & $\mathrm{CR}$ & {$[\%]$} & 0 & 17 & 8.5 \\
\hline Potholes & $\mathrm{PH}$ & {$[\%]$} & 0 & 27 & 13.5 \\
\hline
\end{tabular}

The database was randomly sorted and divided into two parts, referred to as "in-sample" data and "out-of-sample" data. Under "in-sample" data, 120 test sections were considered and under "out-of-sample" data, 53 test sections were considered. To eliminate any bias while dividing the data as "in-sample" and "outof-sample", the test sections were randomly sorted and divided [18]. The in-sample part forms the bulk of the data with about 70 percent of the data. It was used in developing the regression equation. The remaining 30 percent of the data, referred as the "out-of-sample" data were used for validation.

The roughness value was taken as the response variable and the measured pavement distress parameters, namely cracking and potholes, were considered as explanatory variables. A good correlation exists between roughness and the other two explanatory variables. It was observed that the significance of explanatory variables in descending order involved cracking and potholes. The best model obtained using multiple linear regression analysis is:

\section{$\mathrm{ROU}(\mathrm{m} / \mathrm{km})=3.232+0.250 \mathrm{CR}+0.123 \mathrm{PH}$}

$\left(R^{2}=0.814, S E=1.027, N=120\right)$

\subsection{Statistical validity of the model}

To check statistical validity of the models and significance of the variables, a well-known "student-t" values and "p-values" were calculated for each of the variables in the models as presented in Table 2.

Table 2. Statistical data for roughness prediction model

\begin{tabular}{|c|c|c|c|c|}
\hline $\begin{array}{c}\text { Dependent } \\
\text { variable }\end{array}$ & $\begin{array}{l}\text { Independent } \\
\text { variable }\end{array}$ & Coefficients & Student-t & $\mathrm{p}$-value \\
\hline \multirow{2}{*}{ 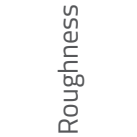 } & Cracking & 0.249 & 5.208 & 0.000 \\
\hline & Potholes & 0.123 & 3.302 & 0.001 \\
\hline
\end{tabular}

The acceptable "student-t" statistical value for $95 \%$ confidence level is 1.645. It can be observed from Table 2 that the student $t$ values estimated for both distresses are greater than 1.645 which implies that the response variable follows a normal distribution with a constant variance across the observation. These values represent the confidence of the model parameters at $95 \%$ confidence interval. Table 2 shows that $p$ values for both distress parameters are less than 0.05 and therefore all the variables included in the model were accepted and found to be significant for model development.

Regression statistics and ANOVA results are also presented in Tables 3 and 4, respectively. Table 3 shows that the value of "Multiple R" is 0.902 for roughness, which points to the correlation between the roughness value and other two distresses, namely cracking and potholes.

It can also be seen from Table 3 that the Standard Expected Error between the observed and predicted roughness values is 1.02 $\mathrm{m} / \mathrm{km}$. From ANOVA results of the model presented in Table 4, it can be observed that the value of "Significance $F$ " is less than 0.05 , which shows that the developed model is significant.

Table 3. Regression statistics of roughness model

\begin{tabular}{|c|c|}
\hline Regression statistics & Roughness model \\
\hline Multiple $\mathrm{R}$ & 0.902 \\
\hline $\mathrm{R}^{2}$ & 0.814 \\
\hline Adjusted $\mathrm{R}^{2}$ & 0.810 \\
\hline Standard error & 1.027 \\
\hline Number of observations & 120 \\
\hline
\end{tabular}

Table 4. ANOVA results of roughness model

\begin{tabular}{|c|c|c|c|c|c|}
\hline \multicolumn{7}{|c|}{ Roughness model } \\
\hline $\begin{array}{c}\text { Source of } \\
\text { variability }\end{array}$ & $\begin{array}{c}\text { Degrees of freedom } \\
\text { (Df) }\end{array}$ & $\begin{array}{c}\text { Sum of squares } \\
\text { (SS) }\end{array}$ & $\begin{array}{c}\text { Mean sum of squares } \\
\text { (MS) }\end{array}$ & $\begin{array}{c}\text { Statistics } \\
\text { F }\end{array}$ & $\begin{array}{c}\text { Significance } \\
\text { F }\end{array}$ \\
\hline Regression & 2 & 540.870 & 270.435 & 256.182 & $1.79 \times 10^{-43}$ \\
\hline Residual & 117 & 123.509 & 1.055 & - & - \\
\hline Total & 119 & 664.379 & - & - & - \\
\hline
\end{tabular}




\subsection{Model validation}

In order to explain robustness of the model, a plot is made between observed roughness values of 53 independent test sections, which were not considered for model development, and predicted roughness values from the model, as shown in Figure 2. The alignment of plotted points along the line of equality shows robustness of the model.

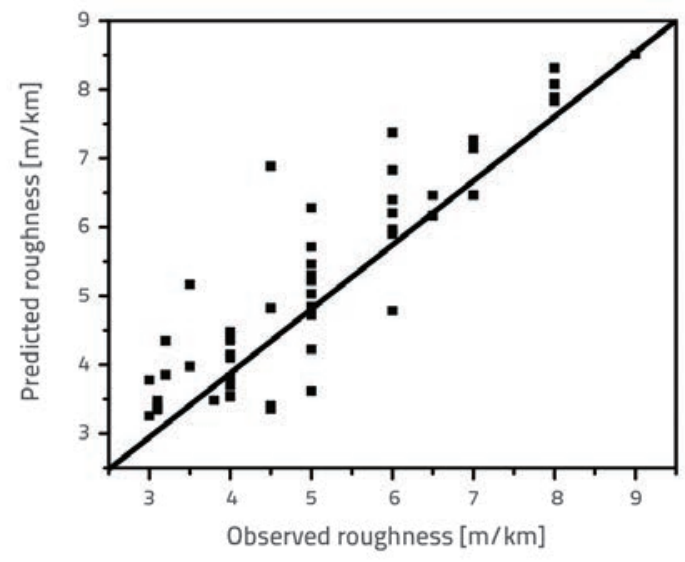

Figure 2. Comparison between predicted and observed roughness values based on the out of sample data

\subsection{Sensitivity analysis of roughness model}

To explain sensitivity of roughness (IRI) to cracking, a plot is made between arbitrary cracking values and the corresponding roughness values obtained from the developed model considering mean values of potholes of test sections taken in this study (Figure 3). In this graph, the steepness of the line indicates the sensitivity of the model for even a small change in cracking value. It can be observed that the roughness value increases by $0.25 \mathrm{~m} / \mathrm{km}$ when the cracking value increases by $1 \%$.

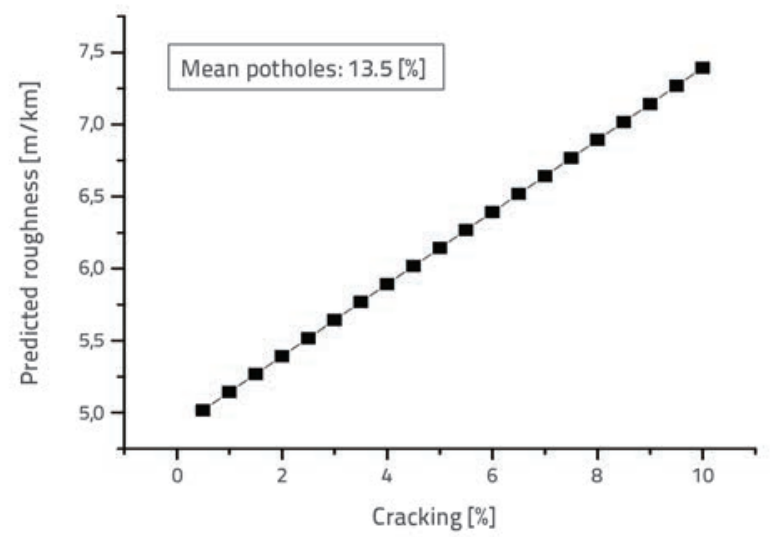

Figure 3. Plot showing arbitrary cracking values and the corresponding roughness values for sensitivity analysis
To explain the sensitivity of roughness (IRI) to potholes, a plot is made of arbitrary pothole values and the corresponding roughness values obtained from the developed model considering mean values of cracking of test sections taken in this study (Figure 4). In this graph, the steepness of the line indicates the sensitivity of the model to even a small change in the pothole value. It can be observed that the roughness value increases by $0.123 \mathrm{~m} / \mathrm{km}$ when the potholes value increases by $1 \%$.

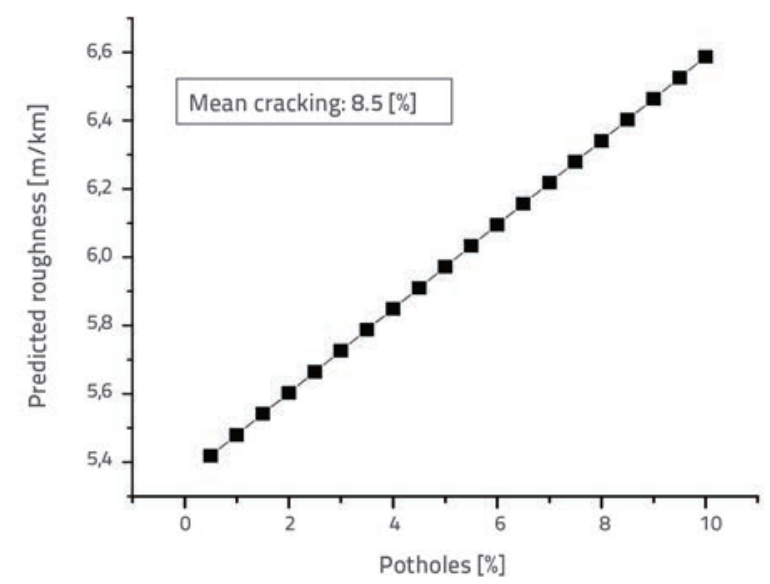

Figure 4. Plot of arbitrary pothole values and the corresponding roughness values for sensitivity analysis

\section{Ground truth study}

Roughness values on 18 roads were measured for ground truth verification. It can be seen that the actual roughness value is very close to the value obtained by the model, which points to the strength of the model developed in this study. The information about the age of the roads, Cracking (CR), Potholes $(\mathrm{PH})$, and roughness values for selected stretch, is presented in Table 5. The roughness value for all newly constructed roads with $0 \%$ cracking and potholes was maintained as $3.0 \mathrm{~m} / \mathrm{km}$. whereas the roughness value for the same conditions of potholes and cracks obtained from the model developed is $3.232 \mathrm{~m} / \mathrm{km}$.

According to Table 5 for the Pinjivakkam road constructed in February 2014, the measured roughness value was $4.5 \mathrm{~m} /$ $\mathrm{km}$ and the predicted roughness value was 4.3 at the end of October 2015. The roughness value for the remaining stretches was tabulated in the same way.

The appearance of the Pinjivakkam road immediately after construction in February 2014 and after use in October 2015 is shown in Figure 5 and Figure 6, respectively. 
Table 5. Ground truth verification detail

\begin{tabular}{|c|c|c|c|c|c|c|c|c|}
\hline No. & $\begin{array}{l}\text { Ground truth study } \\
\text { stretches }\end{array}$ & $\begin{array}{l}\text { Newly } \\
\text { constructed } \\
\text { road in month } \\
\text { and year }\end{array}$ & $\begin{array}{l}\text { Ground truth } \\
\text { verification in } \\
\text { month and year }\end{array}$ & $\begin{array}{c}\text { Age of road } \\
\text { [years] }\end{array}$ & $\begin{array}{l}\text { CR } \\
{[\%]}\end{array}$ & $\begin{array}{l}\mathrm{PH} \\
{[\%]}\end{array}$ & $\begin{array}{c}\text { Predicted } \\
\text { roughness } \\
\text { value from } \\
\text { the model } \\
{[\mathrm{m} / \mathrm{km}]}\end{array}$ & $\begin{array}{c}\text { Measured } \\
\text { roughness } \\
\text { value from } \\
\text { the field } \\
{[\mathrm{m} / \mathrm{km}]}\end{array}$ \\
\hline 1 & Pijivakkam road & February 2014 & October 2015 & 2.0 & 3.1 & 2.4 & 4.3 & 4.5 \\
\hline 2 & $\begin{array}{l}\text { Naapalayam - } \\
\text { Vellivoyal Road }\end{array}$ & January 2010 & February 2013 & 3.0 & 10 & 7 & 6.5 & 6.5 \\
\hline 3 & CT-Adhivaragapuram & January 2010 & July 2013 & 3.5 & 5.5 & 9 & 5.7 & 5.5 \\
\hline 4 & Kolur - Puducherimedu & October 2010 & October 2014 & 4.0 & 5.0 & 6.7 & 5.3 & 5.0 \\
\hline 5 & $\begin{array}{l}\text { Thottimedu - } \\
\text { Annamalaicheri }\end{array}$ & October 2010 & April 2015 & 4.5 & 7.5 & 7.0 & 5.9 & 6.0 \\
\hline 6 & $\begin{array}{l}\text { Tirur - Agricultural } \\
\text { form road }\end{array}$ & April 2013 & April 2015 & 2.0 & 2.0 & 4 & 4.2 & 4.1 \\
\hline 7 & $\begin{array}{l}\text { R.K. Pet - Pallipet - } \\
\text { sanankuppam road }\end{array}$ & November 2012 & April 2015 & 2.5 & 6.0 & 4 & 5.2 & 5.0 \\
\hline 8 & $\begin{array}{l}\text { GNT Road - Vettukadu } \\
\text { road }\end{array}$ & November 2012 & May 2015 & 2.5 & 3.9 & 5 & 4.8 & 4.5 \\
\hline 9 & $\begin{array}{l}\text { WS Road - Neeloth } \\
\text { Balapuram Road }\end{array}$ & November 2012 & May 2015 & 2.5 & 4.0 & 6.5 & 5.0 & 5.0 \\
\hline 10 & $\begin{array}{c}\text { Elavoor - } \\
\text { Kokkupalayam Road }\end{array}$ & April 2011 & May 2012 & 1.0 & 1.0 & 0 & 3.4 & 3.4 \\
\hline 11 & Elambakkam - Koovam & April 2013 & December 2014 & 1.5 & 1.2 & 2 & 3.7 & 3.5 \\
\hline 12 & $\begin{array}{c}\text { Ayyaneri - } \\
\text { Rukmanipuram }\end{array}$ & May 2013 & January 2015 & 1.5 & 1.4 & 2 & 3.8 & 3.8 \\
\hline 13 & $\begin{array}{l}\text { MTR Road - } \\
\text { Perumalpattu - } \\
\text { Kottamedu Road }\end{array}$ & May 2013 & February 2015 & 1.5 & 1.0 & 3 & 3.8 & 3.5 \\
\hline 14 & $\begin{array}{l}\text { Dunlop Nagar - } \\
\text { Ayathur Road }\end{array}$ & July 2013 & March 2015 & 1.8 & 1.7 & 4 & 4.1 & 4.0 \\
\hline 15 & $\begin{array}{l}\text { GNT road - sidaraja } \\
\text { kandigai }\end{array}$ & July 2013 & April 2015 & 1.9 & 2.5 & 4.5 & 4.4 & 4.1 \\
\hline 16 & $\begin{array}{l}\text { Kuppam Kandigai - } \\
\text { Mosur Road }\end{array}$ & January 2014 & June 2015 & 1.5 & 1.5 & 4 & 4.0 & 4.0 \\
\hline 17 & $\begin{array}{l}\text { Vichoor to VCN } \\
\text { Kandigai Rd }\end{array}$ & September 2013 & September 2015 & 2.0 & 1.5 & 6 & 4.3 & 4.2 \\
\hline 18 & $\begin{array}{c}\text { Velur - Erupallikuppam } \\
\text { Road }\end{array}$ & October 2013 & October 2015 & 2.0 & 2.0 & 6 & 4.4 & 4.1 \\
\hline
\end{tabular}

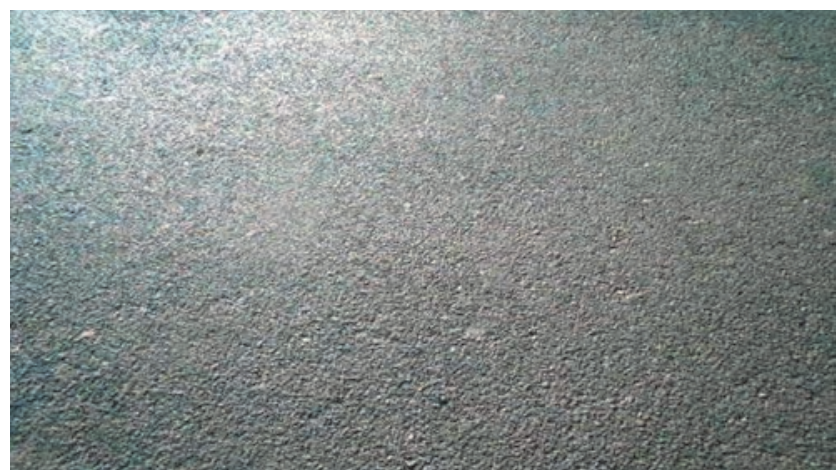

Figure 5. New road surface in February 2014

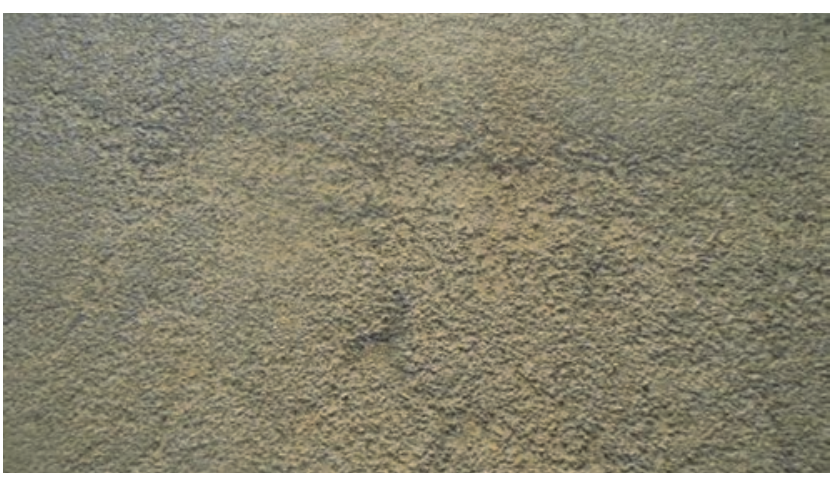

Figure 6. Road surface in October 2015 


\section{Conclusions}

The following conclusions can be drawn from the analysis of data collected at 173 test sections in the Thiruvallur District of Tamil Nadu State in India:

- A good relationship has been established in this study between the road surface roughness value and the distresses, namely cracking and potholes, with $\mathrm{R}^{2}$ value of 0.814 .

- The model developed in this study was thoroughly evaluated for its effectiveness by validation process, and was thereafter tested through ground truth verification to understand its accuracy.

- Cracking and potholes can be measured with simple measuring tape even by unskilled manpower, and roughness value can be obtained indirectly from cracking and pothole values, and the use of bump integrator for measuring roughness value can be eliminated if desired.

- The lack of skilled manpower and non-availability of roughness measuring device due to paucity of funds are the major problems for agencies involved in the maintenance of low volume village roads in India. The model developed in this study is highly useful for these agencies as it enables planning their maintenance strategies based on roughness value.

The model has been developed in this study with traffic volume ranging between 2 and 9 commercial vehicles per day. Hence, this model can effectively be used for such very low traffic volume conditions only.

\section{REFERENCES}

[1] Makendran, C., Murugasan, R., Velmurugan, S.: Performance prediction modelling for flexible pavement on low volume roads using multiple linear regression analysis, Journals of Applied Mathematics, 192485 (2015), pp. 1-7, https://doi. org/10.1155/2015/192485

[2] AASHO, Pavement Research, Highway Research Board, National Academy of Sciences-National Research Council, Washington D.C., USA, AASHO Road Test Report No.5, 1962.

[3] Queiroz, C.A.V., Hudson, W.R.: Improved pavement performance relationship in brazil," Fifth International Conference on the Structural Design of Asphalt Pavements, Proceedings, The University of Michigan, Ann Arbor, Michigan, 1 (1982), pp.500510

[4] CRRI.: Pavement performance study on existing sections, Project Sponsored by Ministry of Surface Transport, Government of India, Final Report, Submitted by Central Road Research Institute, New Delhi,1994

[5] Bennet, C.R., Paterson, W.D.O.: A guide to calibration and adaptation, HDM-4 Highway Development and Management, International study of highway development and management tool, the world road Association, Paris, France, 5 (2000).

[6] Oliveira de Souza, R., Dantas Neto, S., Muniz de Farias, M.: Statistical analysis between roughness indices and roughness prediction model using neural networks', International contest on long term pavement performance sponsored by federal highway administration and the American society of civil engineers. pp. 1-19, 2004

[7] Smith, T.J., Tighe, L.S.: Assessment of overlay roughness in the LTPP-a Canadian case study International contest on long term pavement performance sponsored by federal highway administration and the American society of civil engineers, pp. 57-68, 2004.

[8] Terzi, S.: Modeling the pavement serviceability ratio of flexible highway pavements by artificial neural networks, Elsevier, Construction and Building Materials, 21 (2006), pp.590-593, https://doi.org/10.1016/j.conbuildmat.2005.11.001
[9] Ankit, G., Praveen, K., Rajat, R.: Pavement deterioration and maintenance model for low volume roads, International Journal of Pavement Research and Technology, 4 (2011) 4, pp. 195-202

[10] Amarendra, K.S., Ashoke, K.S.: Development of a model for estimating International Roughness Index from pavement distresses, International Journal of Pavement Engineering, Taylor \& Francis, pp.1-10, 2012

[11] Sugeng, W.: The application of traffic simulation model to predict initiation and progression of crack for flexible pavements, Elsevier, Procedia - Social and Behavioral Sciences, 43 (2012), pp.813-818, https://doi.org/10.1016/j.sbspro.2012.04.156

[12] Vandana, T., Goliya, H.S., Bhatore, A., Kundan, M.: Pavement deterioration modelling for low volume roads, Indian Highways, 73 (2013) 4, pp. 67-81

[13] Prasad, P.J., Shalini, K., Pooja, N., Bhanegaonkar, S.A.K., Shriniwas, A.: Development of relationship between roughness (IRI) and visible surface distresses: A study on PMGSY roads, Procedia Social and Behavioral Sciences, 104 (2013) 2, pp. 322-331.

[14] Satish, C., Chalumuri, R.S., Anish, K.B., Kangadurai, B.: Relationship between Pavement Roughness and Distress Parameters for Indian Highways, Journal of Transportation Engineering, 139 (2013) 5, pp. 467-475.

[15] IRC, SP 20-2002, Rural road manual, Indian Road Congress, New Delhi, India, 2002

[16] MORTH, Specifications for road and bridge work, Ministry of Road Transport and Highways, New Delhi, India, 2001.

[17] IRC, 9-1972, Traffic census on non-urban roads, Indian Road Congress, India. 1972.

[18] Prozzi, J.A.: Modelling pavement performance by combining field and experimental data', Doctorate of Philosophy Dissertation, University of California, Berkeley. 2001. 